\title{
Some Saskatchewan Legumes
}

\author{
Arch C. Budd, Swift Current, Saskatchewan.
} (Continued)

\section{GLYCYRRHIZA- (Wild Licorice)} genus. 1 species.

1. Glycyrrhiza lepidota (Nutt.) Pursh WILD LICORICE.

A coarse branching plant from 1 to 3 feet high, from a thick, sweet tasting rootstock, with a slight licorice flavour. 'The leaves bear from 11 to 19 lanceolate-oblong leaflets, pale green, glandular dotted, from

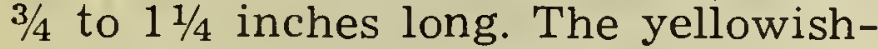
white flowers are about $1 / 2$ inch long and borne in dense racemes from 1 to 2 inches long. The fruit are oblong, reddish-brown pods about $1 / 2$ inch long and covered with hooked prickles. Very common on low lying land and moist spots throughout the entire province.

\section{HEDYSARUIMI- (Sweet B r o o m) genus. 3 species.}

Perennial herbs with pinnate leaves, the flowers generally reflexed in long spikelike racemes. The pods or loments are flat and jointed or constricted between the seeds.

1.Calyx teeth triangular and very unequal, the upper shorter than the calyx tube; veins of leaflets conspicuous. Calyx teeth linear and nearly equal, about as long as calyx tube; veins of leaflets not conspicuous.

(1) H. alpinum-2.

2. Inflorescence elongated; stipules dark brown.

(2) $H$. boreale.

Inflorescence congested; stipules whitish and semi-transparent.

(3) H. MacKenzii.

1. Hedysarum a $\mathrm{lp}$ in um L. var. americanum Michx.

AMERICAN HEDYSARUTM

An erect plant from 6 to 30 inches high. The leaves bear from 11 to 21 oblong leaflets from $1 / 2$ to $1 \frac{1 / 4}{4}$ inches long and the flowers are borne in a long raceme and are pinkish or violet in colour, generally reflexed and from $1 / 2$ to $5 / 8$ inch long. The loments or pods generally have 3 to 5 internodes or enlargements and are practically hairless. This plant is common in the northern wooded parts of the province and in the Cypress Hills area. It is readily eaten by livestock.
2. Hedysarum boreale Nutt. var. cinearascens (Rydb.) Rollins.

SILVERY HEDYSARUMI

A somewhat decumbent plant from 12 to 20 inches high, with the leaflets covered with fine, smooth, silky hairiness. The purplish flowers are very conspicous. The deeply wrinkled loments have from 3 to 4 internodes. Fairly common on dry hillsides in the south-western part of the province.

3. Hedysarum Mackenzii Richards. MACKENZIE'S HEDYSARUM

A little-branched, erect species from 8 to 16 inches high, the leaflets often with fine grayish hairiness beneath. The flowers are rather larger than the other species, being about $3 / 4$ inch long, rose-purple in colour and borne in a short dense raceme. Somewhat rare but found in meadow lands across the province.

\section{LATHYRUS- (Vetchling) g e n us.}

3 species.

Twining vines, dying, back to ground each year, with pinnate leaves with a tendril replacing the end leaflet.

1. Flowers cream or yellowish.

\section{Flowers purple.}

(1) L. ochroleucus.

2. Leaflets inear or linear-lanceolate; 2 to 8 flowers in each raceme.

(2) L. palustris.

Leaflets broadly oval; 8 to 20 flowers to raceme.

(3) L. venosus.

1. Lathyrus ochroleucus Hook.

\section{CREAM-COLOURED}

VETCHLING.

A smooth climber up to 3 feet long with somewhat angled stems and large, almost cordate stipules and oval leaflets from 1 to 2 inches long. The cream-coloured flowers are borne from 5 to 10 to a raceme. Very common in wooded areas throughout the entire province.

2. Lathyrus palustris L.

\section{MARSH VETCHLING}

A smooth climber from 1 to 3 feet long with somewhat winged stems, small stipules and linear leaflets from $1 / 2$ to $2 \frac{1}{2}$ inches long. There are from 2 to 8 purple flowers to each raceme. Fairly common in the northern moist areas of the province. 
3.Lathyrus venosus Muhl.

WILD PEA-VINE.

A strongly four-angled stemmed climber from 2 to 3 feet long, sometimes finely hairy. The leaflets are oblong-oval from 1 to 2 inches long. There are from 12 to 20 purplish flowers in each raceme. Very common in bushy land throughout the northern parts of the province and makes a valuable hay and forage plant.

\section{LUPINUS- (Lupine) genus.}

\section{2 species.}

Perennial herbs with palmate leaves and showy flowers.

1. Perennial; tall growing and erect.

(1) L. argenteus.

Annual; low growing hairy plants.

(2) L. pusillus.

1. Lupinus argenteus Pursh.

SILVERY LUPINE.

A rather shrubby branching herb from .1 to 2 feet in height, the stems and leaves finely appressed silkyhairy. The leaves bear from 6 to 9 narrow leaflets in finger like fashion, each from $3 / 4$ to 2 inches long. The showy bluish flowers are borne in long terminal racemes. Quite common in the Cypress Hills area and also in a few localities to the east of them.

2. Lupinus pusillus Pursh.

SMALL LUPINE.

A very hairy, low growing annual plant from 4 to 6 inches high, with palmate leaves bearing 5 oblong leaflets. The pale bluish-purple flowers are borne in short dense terminal racemes. Only found in very sandy places and on sand dunes.

OXYTROPIS- (Loco-weed) genus.

6 species.

Perennial herbs, generally with no apparent stem. The keel, or lower petal of the flower is tipped by a small point, thus distinguishing this genus from Astragalus.

1. Stems well developed. Leafy; pods pendulous. (1) O. deflexa.

No apparent stems. Pods not pendulous.

-2 .

2. Leaflets in whorls, plant woolly.

(5) O. splendens.

Leaves pinnate, leaflets opposite. -3 .

3. Flowers purple, rarely white.

(3) O. Lambertii.

Flowers yellow or cream-coloured.
4. Flowers $5 / 8$ to $3 / 4$ inch long; early flowering. (4) O. Macounii.

Flowers less than $5 / 8$ inch long. (2) O. gracilis.

1. Oxytropis deflexa (Pall.) DC.

REFLEXED LOCO-WEED

A plant from 4 to 16 inches high with branching stems and from 25 to 41 leaflets to each leaf. The small blue-tipped whitish flowers are in loose racemes and the pods pendulous or reflexed. Fairly common in moist places throughout the entire province.

\section{Oxytropis gracilis (A. Nels.) K. Schum. \\ LATE YELLOW LOCO-WEED.}

A tufted plant with leaves bearing from 21 to 31 appressed haired leaflets. The cream-coloured flowers are borne in a close raceme on a stem from 8 to 16 inches high. Quite common on hillsides and prairie where conditions are not too dry across the entire province. It generally blooms in July.

3. Oxytropis Lambertii Pursh.

PURPLE LOCO-WEED.

A species from 6 to 14 inches high with fine silky-appressed hairs. The flowers seem to vary from red or bluish-purple to yellowish-white. It is very rare in our province but has been reported from the south-central portion.

4. Oxytropis Macounii (Greene) Rydb.

EARLY YELLOW LOCO-WEED.

A low growing species with leaves bearing from 7 to 21 leaflets, short silky haired. The flowers are yellow and longer than those of $O$. gracilis, and the flowers appear quite early in May or June. This species is the Loco-weed which is so troublesome to livestock. It is very plentiful on dry hillsides and upland prairie.

5. Oxytropis splendens Dougl.

SHOWY LOCO-WEED.

This species grows in clumps and bears long, soft silky hairs. The leaflets are in whorls around the leaf stem thus distinguishing this from other Loco-weeds. The flowers are dark blue and borne in dense hairy spikes. Common in the southern parts of the province but replaced westward by the appressed haired variety Richardsonii Hook. 